Europe, has naturally led Professor Daly to a different conclusion. Why it alone should be undeformed, lying as it does among the highly warped shorelines of North America, is a mystery which the tracing of it into other areas may ultimately solve. Its parallelism to the modern shore is the more puzzling, as Gilbert seems to have proved that the warping of the Great Lakes Region is, like that of Scandinavia, still progressing. As regards the very widely distributed raised shorelines and reefs of tropical seas, the writer has long thought that they are more probably the equivalent of the pre-Glacial shoreline of Europe than of any of the later raised beaches. Maufe was inclined to hold the same view when he was working on the raised reef at Mombasa. If this is the case, the conclusion must be that the ocean, after the Glacial oscillations, has returned to a level a little lower than that of pre-Glacial times.

DebLin,

W. B. WRIGHT.

June 15,1920 .

[We regret that this letter was received too late for insertion in the July number.-ED. Geot. MaG.]

\title{
THE BOURNEMOUTH CLIFFS.
}

SiR,-I have no desire to prolong this discussion, but as I have been asked where photographs of the cliffs, as they appeared about thirty years ago, may be seen, I should like to refer those who are interested to one illustrating an article on "Scientific Aspects of Bournemouth ", which appeared in Research of December 2, 1889.

Yours faithfully,

C. Carus-Wilson.

\section{OBITUARY.}

BORN 1814.

GEORGE SWEET, F.G.S.

DIED 1920.

Mr. George SwEEt, who recently died at the age of 76 , was born at Salisbury, England, but spent most of his life as a manufacturer of pottery near Melbourne, Australia. He was a keen geologist, and was second in command of the second Funafuti expedition under Professor Edgeworth David. He also made extensive collections of fossils from the Carboniferous and Cretaceous strata of Queonsland, and investigated the Permo-Carboniferous glacial beds of Bacchus Marsh. In 1905 he was President of the Royal Society of Victoria. 